\title{
The 13th IEEE International Conference on Nanotechnology, IEEE-Nano 2013 報告
}

\author{
中島 正博 (名古屋大学)
}

\section{1. はじめに}

第 13 回 IEEE International Conference on Nanotechnology (IEEE-Nano 2013) が 2013 年 8 月 5 日か ら 8 月 8 日まで 4 日間, 中国（北京）で開催された。本会 議は, アメリカの電気・電子技術の学会である IEEE（The Institute of Electrical and Electronics Engineers）におけ る, IEEE-Nanotechnology Council が主催するナノテクノ ロジー関連の学会としては 2001 年にてアメリカ・ハワイで 開催されてから最も歴史がある国際会議である。

今回は, 北京の Shangrila Hotel にて開催され，北京国際 空港から 30 分程度で比較的アクセスは良かった。

\section{2. 会議の概要}

論文数は，297 件で，うち 255 件の学術論文と 42 件の招 待論文であった。また, 参加者はバンケットの時点で, 1186 名が 39 国から参加した。参加者の数が多い国から, 中国, アメリカ, 台湾, 日本, 韓国, イギリスの順であった。

プログラム全体としては，8月 5 日には 6 件のチュート リアル， 8 月 6 日には 2 件の基調講演, 6 パラレル・テクニ カルセッション, 8 月 7 日には 2 件の基調講演, 2 件の招待 講演, 6 パラレル・テクニカルセッション， 8 月 8 日には 5 パラレル・テクニカルセッションが行われた。また， 8 月 7 日には，オープンフォーラム Frontiers in Nanotechnology が開催され，本分野を牽引する著名な先生方が壇上に上が り, ナノテクノロジーの現状や将来展望などについて議論が 交わされた。会場からも多数，質問やコメントが相次いだ。

4 件の基調講演について概要を述べる。アメリカ・ミシ ガン州立大学の Prof. Ning Xi は, カーボンナノチューブ (Carbon Nanotube, CNT) を用いた IR センシングデバイ スについて講演された。原子間力顕微鏡 (Atomic Force Microscope, AFM) を用いたナノマニピュレーションによ る単一 CNT デバイスの構築や CNT のカイラリティに基 づいた波長の選択性などについて述べられた。スイス・ IBM Zurich Research Laboratory の Dr. Evangelos S. Eleftheriou は，走查型プローブ顕微鏡 (Scanning Probe Microscope, SPM）の新たな応用展開について講演された。 SPM を用いたナノ位置決めを利用したデータストレージを 行う技術などについて述べられた。日本・東京女子医科大 学の大和雅之教授は, 細胞シートを用いた再生医療技術に ついて講演された。細胞シートを用いて, 角膜などの様々な

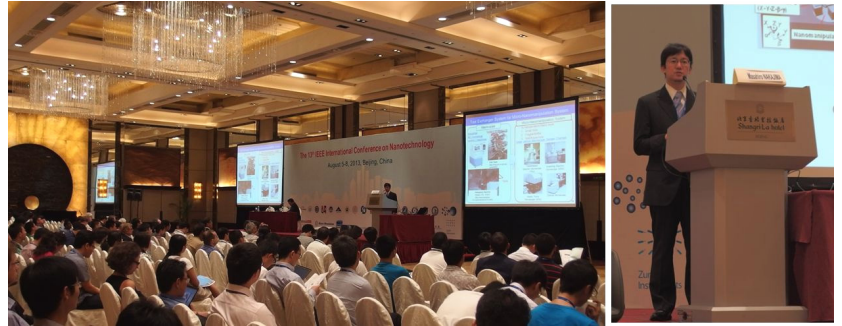

図 1 招待講演の会場と講演中の著者

臟器に臨床応用されている最先端の研究成果とロボット技 術を応用した細胞シート作製の自動化などについて述べら れた。アメリカ・プリンストン大学の Prof. Stephen Y. Chou からは, ナノインプリント技術によるナノファブリケーショ ンについて述べられた。10 nm のピラーやホールを高密度 に集積して加工する新たなナノ加工技術などについて述べ られた。

2 件の招待講演について概要を述べる。韓国・パークシ ステム社から Dr. Sang-il Park からは, 原子間力顕微鏡の 最先端の動向について講演された。クロストーク除去と呼 ばれる原子間力顕微鏡による正確な計測技術や厚みがある 試料に対して有効な走査型イオンコンダクタンス顕微鏡 (Scanning Ion Conductance Microscope, SICM) などに ついて述べられた。著者は, 環境制御型電子顕微鏡 (Environmental- Scanning Electron Microscope, E-SEM) 内でのナノバイオマニピュレーションシステムの構築と線 虫への応用について講演した。湿潤環境において線虫に対 するナノメートルスケールの操作を実現し, 線虫の生存評 価やナノインジェクションなどへの応用に関して述べた。

著者は, 本会議において, IEEE Nanotechnology Council から Early Career Award in Nanotechnology を受賞した。 この場をお借りして，これまでご指導をいただいた諸先生 方に改めて敬意と感謝する次第である。

\section{3. おわりに}

次回は, 2014 年 8 月 18 日から 8 月 21 日にかけてカナダ のトロントにある Eaton Chelsea Hotelにて開催される予 定である。2014 年 3 月 15 日がアブストラクト投稿締切日 であり, 日本からも多数の論文投稿がされることを期待し たい。

(平成 26 年 2 月 10 日受付) 